\author{
Proceedings of DETC/CIE 2006 \\ ASME 2006 International Design Engineering Technical Conferences \& \\ Computers and Information in Engineering Conference \\ September 10-13, 2006, Philadelphia, Pennsylvania, USA
}

DETC2006-99083

\title{
INTEGRATING DESIGN THROUGHOUT THE MECHANICAL ENGINEERING CURRICULUM: A FOCUS ON THE ENGINEERING CLINICS
}

\author{
Krishan Bhatia, Tirupathi R. Chandrupatla, John C. Chen, Eric Constans, \\ Jennifer A. Kadlowec, Anthony J. Marchese, Paris von Lockette, and Hong Zhang \\ Rowan University \\ 201 Mullica Hill Road \\ Glassboro, NJ 08028
}

\begin{abstract}
At Rowan University, we have infused design into the curriculum through an eight-semester course sequence called the Engineering Clinic. Through this experience students learn the art and science of design in a multidisciplinary team environment. While many engineering programs currently include a Capstone Design course taken near the end of the college career to meet the design needs, Engineering Clinic at Rowan allows students to hone their design skills throughout their four-year career. This paper will describe in further detail the objectives and execution of each year in the design sequence, types of projects and how the Clinics complement traditional core courses in the curriculum. Impacts and benefits of the Clinics on students and faculty are discussed, as well as comparative data of Rowan Mechanical Engineering students and their peers nationally.
\end{abstract}

\section{BACKGROUND}

Engineering education has been undergoing many changes brought about by such factors as society's need for more technically trained individuals, pressure to limit credit hours needed to earn a degree, accreditation criteria (i.e., EC2000), industry needs, and a focus on project-based and student-centered learning. Among the many challenges arising from these changes, perhaps the most formidable is the incorporation of more design into the curriculum. Design represents the solution of open-ended problems, usually in the development of a product. The design process challenges students to synthesize, analyze, evaluate and apply the engineering skills, knowledge and tools that they have acquired. While the design skill-set is highly valued in engineering graduates, it is also arguably one of the most difficult to learn and teach. At Rowan University, we have infused design into the curriculum through an eight-semester course sequence called the Engineering Clinic in which students learn the art and science of design in a multidisciplinary team environment.

Most mechanical engineering programs currently include a Capstone Design course to meet the design needs, but this approach has some shortcomings. In a one- or twosemester long course, the need to include such varied skills as communications, project management and teamwork necessarily takes away from the focus on design skills development. Furthermore, the traditional Capstone Design course is not multidisciplinary, which is a valuable experience for preparing students for the workplace. Finally, since the Capstone project occurs at the end of a student's undergraduate career, it does not allow students to continuously apply skills learned in the supporting coursework. Engineering Clinic allows students to practice a wide range of engineering skills in a multidisciplinary environment while honing their design skills throughout their four-year career. ${ }^{1}$

\section{THE ENGINEERING CLINICS}

Rowan University is a comprehensive, state-supported institution with a primary mission of undergraduate education. In 1992, Henry Rowan, a local industrialist, recognized the need for an engineering school in south New Jersey, both to help develop the industrial base of the region and to stimulate its economic growth. In order to do so, he made a $\$ 100$ million gift to then Glassboro State College with the sole stipulation that a high-quality engineering program be created. The first class of engineering students entered in the fall of 1996 and graduated in spring 2000. From the beginning, we developed and implemented the Engineering Clinic sequence, which has continued to, evolve in order to meet the changing needs of our students and the industries that hire them. 
The Engineering College at Rowan is committed to innovative methods of learning to best prepare students for a rapidly changing and highly competitive marketplace. Key objectives of the curriculum include:

- Creating multidisciplinary experiences through collaborative laboratories and coursework;

- Incorporating state-of-the-art technologies throughout the curricula;

- Creating continuous opportunities for technical writing and communication, and

- Emphasizing hands-on, open-ended problem solving, including undergraduate research.

To help meet these objectives, the College of Engineering at Rowan has a common Engineering Clinic sequence throughout the programs of study. The Clinics are an eight-semester course sequence, summarized in Table 1, taken by all engineering students, not only those in Mechanical Engineering. Each clinic class involves students working in teams, often interdisciplinary, on hands-on activities, report writing and presentations. All engineering faculty are involved in the Clinics. Historically Mechanical Engineering (ME) faculty participation is as follows: one or two each lead one of six Freshman Clinic sections, two are involved with the team-taught Sophomore Clinic, and all ME faculty lead at least two Junior/Senior Clinic teams each semester.

\begin{tabular}{|l|l|l|}
\hline Year & Clinic Theme (Fall) & Clinic Theme (Spring) \\
\hline Frosh & $\begin{array}{l}\text { Engineering } \\
\text { Measurements }\end{array}$ & $\begin{array}{l}\text { Competitive Assessment } \\
\text { and Reverse Engineering }\end{array}$ \\
\hline Soph & $\begin{array}{l}\text { Multidisciplinary } \\
\text { Project and } \\
\text { Technical Writing }\end{array}$ & $\begin{array}{l}\text { Multidisciplinary Project } \\
\text { and Public Speaking }\end{array}$ \\
\hline Jr/Sr & Capstone Design or Research Project \\
\hline
\end{tabular}

TABLE 1: Overall structure of the 8-semester Engineering Clinic sequence at Rowan University.

\section{Freshman Engineering Clinic}

The Freshman Clinic consists of a 50-minute lecture class and a 2-hour and 40-minute laboratory focused on engineering measurements in the fall and reverse engineering in the spring. Students from all four disciplines are mixed in six sections of the course. In the fall semester of the freshmen year, students learn basic engineering skills (problem solving, teamwork fundamentals, engineering measurements and computer tools), survival skills such as note and exam taking, and are introduced to the variety of activities in each of the four disciplines at Rowan (Chemical, Civil and Environmental, Electrical and Computer, and Mechanical Engineering). From 1996 to 2004, each of the sections rotated through three different laboratory exercises from each of the four disciplines, for a total of 12 in all. Some laboratory activities include fluidized bed polymer coating, turbine building, circuit building, and making products from $3 \mathrm{D}$ drawings. ${ }^{2}$ Other activities are shown in Table 2.
The course format was changed in the fall of 2005 after years of losing students in the shuffle of moving from $\mathrm{lab}$ to lab and instructor to instructor to learn subject matter from the four disciplines "artificially" through a series of Clinic modules. Students instead were kept with the same instructor for the entire semester and worked on one project or two to three mini-projects. Projects were chosen to be multidisciplinary to retain that important feature of the curriculum and taught such that the different disciplines were interrelated rather than distinct from one another as in previous years.

In the second semester, an intense study of engineering design occurs through reverse engineering ("dissection") and competitive assessment (instrumentation, testing and side-by-side comparison of technical performance for the purpose of improvement) of a consumer product or process. In this manner, students are introduced to design by studying the designs (both good and bad) of other engineers. This exercise also serves to demonstrate to students the importance of working in multidisciplinary teams to design a multidisciplinary product. Professional skill topics included in this semester are communication skills, teamwork, engineering ethics and intellectual property, the latter two of which complement particularly well the course themes of reverse engineering and competitive assessment. Freshman Clinic received cost-shared funding from the NSF in 1998 to build five "competitive assessment stations" - workstations with a PC, data acquisition, temperature, pressure and flow transducers, function generators, oscilloscope, and hand tools - for this activity.

\begin{tabular}{|l|l|l|}
\hline Discipline & \multicolumn{1}{|c|}{ Fall } & \multicolumn{1}{c|}{ Spring } \\
\hline ChE & $\begin{array}{l}\text { Fluidized bed } \\
\text { polymer coating, } \\
\text { Drug delivery, Food } \\
\text { engineering }\end{array}$ & $\begin{array}{l}\text { Beer brewing, } \\
\text { Engineering } \\
\text { principles of the } \\
\text { human body }\end{array}$ \\
\hline CEE & $\begin{array}{l}\text { Beams, Bridges, } \\
\text { Water quality, } \\
\text { Water treatment, } \\
\text { Turbines, } \\
\text { Sustainability }\end{array}$ & $\begin{array}{l}\text { Portable hiking } \\
\text { water filters, } \\
\text { aquarium }\end{array}$ \\
\hline ECE & $\begin{array}{l}\text { Computer } \\
\text { programming, } \\
\text { Communication } \\
\text { circuits, } \\
\text { Photovoltaics, } \\
\text { Digital counters }\end{array}$ & $\begin{array}{l}\text { Electric } \\
\text { toothbrushes, Blood } \\
\text { pressure monitors, } \\
\text { CO detectors }\end{array}$ \\
\hline ME & $\begin{array}{l}\text { 3D drawing, 3D } \\
\text { prototyping, Gears } \\
\text { and mechanisms, } \\
\text { Programming, } \\
\text { LEGO }{ }^{\circledR} \text { robotics }\end{array}$ & $\begin{array}{l}\text { Wind up/solar } \\
\text { radios, Computer } \\
\text { mice, } \\
\text { Thermoelectric } \\
\text { coolers, Soccer } \\
\text { helmets }\end{array}$ \\
\hline
\end{tabular}

TABLE 2: Freshman Clinic Activities since Fall 2000, by Discipline of Faculty. 
In the most recent offering of Freshmen Clinic I (Fall 2005), the project selected was the construction of LEGO ${ }^{\oplus 5}$ Mindstorm ${ }^{\text {M }}$ robotic cars (Figure 1). This project was chosen since it easily incorporated content from multiple disciplines through such concepts as gears, mechanisms, materials, computer programming, dimensioning and tolerance. The project naturally lent itself to the development of teamwork, open-ended problem solving and communications skills, as the students were placed into two-person teams of different disciplines and presented with challenges to various competitions, including a final obstacle course.

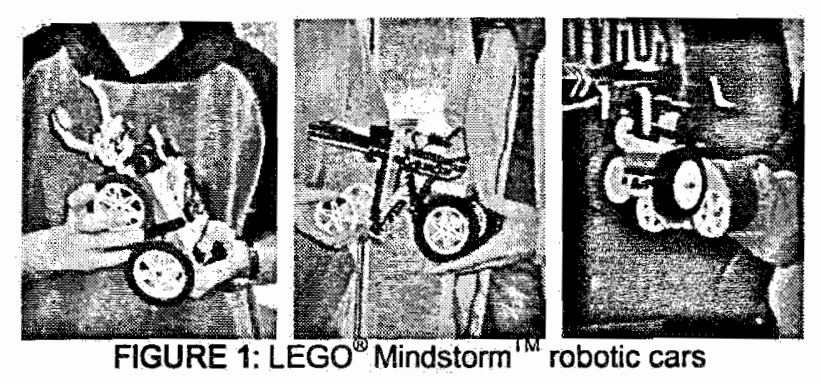

In Spring 2005, our Freshmen Clinic II project involved the design and engineering of soccer helmets (Figure 2). This project allowed the students to first reverse engineer a variety of helmets to gain insight into their design and construction. Students then evaluated current research concerning the effectiveness of these helmets in preventing head injury. After understanding the current state of the art, student teams then went about designing their own experiments which addressed the shortcomings found in previous experimental studies. These student designed experiments involved everything from instrumented crash test dummies to impact rails. Armed with extensive data on acceleration of the head, deflection of the neck, damage to the helmet, and rebound of the ball, student teams were able to evaluate each helmet for effectiveness in preventing injury, minimal intrusiveness towards the player during game play and durability.

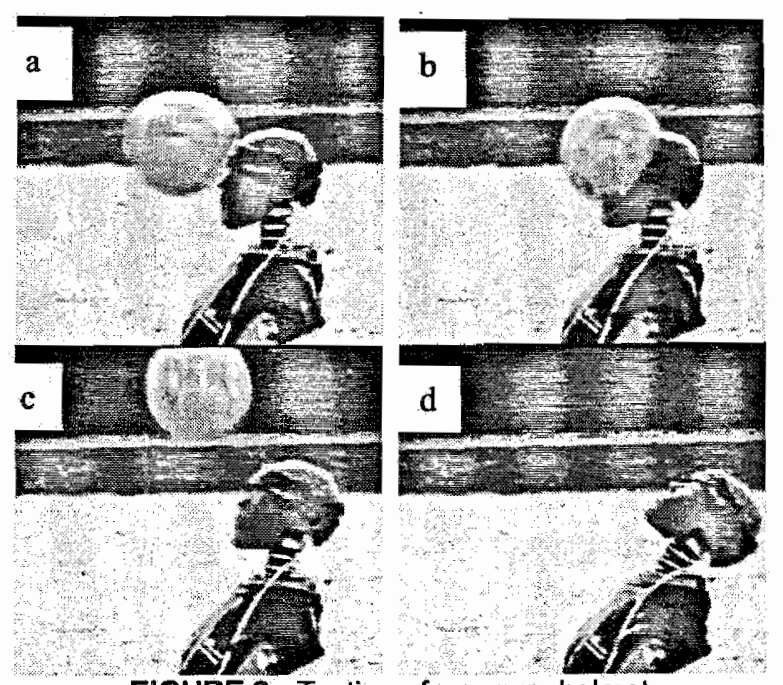

FIGURE 2: Testing of a soccer helmet
In the Spring 2006 semester of Freshmen Clinic II, our reverse engineering project is proton exchange membrane fuel cells. Students learned the science that underlies this technology, how they are constructed, the larger societal issues that surround this technology and the measures of merit for their performance.

\section{Sophomore Engineering Clinic}

The Sophomore Clinic is focused on integrating engineering design with significant communication components, writing in the fall semester and public speaking in the second semester. ${ }^{1,2}$ The students spend 2hours and 40-minutes in a single engineering lab period and 50 minutes in each of three communications periods per week. The course is team taught by faculty from multiple departments within the College of Engineering and the College of Communication and again the sections are mixed such that teams have four to five students from the different disciplines. Assignments and grading are integrated through both communications- and engineeringspecific sections, a trend which is gaining national acceptance. $^{3,4}$

The sophomore clinic course consists of design projects that traditionally have been tied to the mechanical engineering curriculum and thus serve as a "laboratory" component for core courses. ${ }^{5}$ Mechanical engineering students take the two semesters of sophomore clinic concurrently with statics, dynamics and solid mechanics over the course of the academic year and prior to electronic networks, a course in circuit analysis, in the junior year. In the fall semesters of 2003, 2004 and 2005, the Hoistinator Project (Figure 3) tasked students with designing truss systems to lift loads between 420 and $1400 \mathrm{lbs}$. a height of 36 inches, using a maximum of $150 \mathrm{in}^{3}$ of aluminum and 50 in $^{3}$ of plastic as construction materials. Students were not allowed to test their cranes before the final, graded competition which forced them to rely on their analytical "classroom" skills and performing statics and failure calculations that were learned in statics and solid mechanics courses. The project also drew upon concepts from all four engineering disciplines. The teams improved their professional skills by conducting lifecycle and present worth analyses, and they were rewarded for economic and environmentally friendly designs. Also, each team designed and built a digital timing circuit to determine the exact time required to lift the weight the 36 inches.

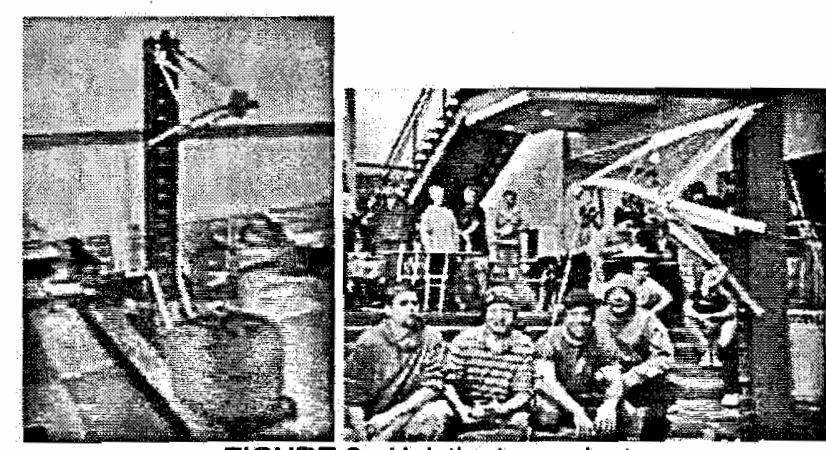

FIGURE 3: Hoistinator project 
Past spring (second) semester projects in sophomore clinic have included the design and construction of golf ball launchers, two degree of freedom cranes, and small motorized vehicles. In these projects links, to the curriculum focus and expand on topics covered in dynamics and electrical networks. For example, in a different past project, the golf ball launcher, students constructed devices which use a spring to drive a plunger which impacts a golf ball. They analyze the impulse imparted to the golf ball by converting the energy stored in the spring-driven system into a resultant harmonic motion of the plunger which is then converted into an impulse to the golf ball. These second semester projects also often include the wiring of LED displays and counting circuits, and the design of power circuitry using MOSFETs to make the connection with the electrical networks course.

\section{Junior / Senior Engineering Clinic}

In the final four semesters of a student's career, the Clinics continue with the format of multidisciplinary teamwork with the added dimensions of semester or yearlong projects and the inclusion of both Junior- and Seniorlevel students in 3-5 member teams. In Mechanical Engineering guiding principles for the Junior/Senior Clinic is "Design, Analyze, Build, and Test". Each multidisciplinary team works closely with one to two professors, often from two different disciplines, who act as project managers to advise the team.

Since the fall of 1998, the Junior/Senior Clinic projects have been inspired by a mix of industry-sponsored activities, professors' research activities, professional society competitions and student or faculty entrepreneurial projects and typically centered on a multidisciplinary technical problem, product or process.

The Mechanical Engineering Department has established many relationships with industry partners for students to work on real-world projects. Some of these partners include NAVSEA - Philadelphia, NAVAIR Lakehurst, Lockheed-Martin, FAA Tech Center, Continental Tire, Damar Inc., Coriell, RL Associates, Durabar, Carlisle Machine Works, Children's Hospital of Philadelphia and Stryker Orthopaedics. They have brought projects to Rowan such as: Improved Design of an Antenna Transfer Assembly Seal and Bearing, Redesign of Navy Jet Blast Deflector, Fatigue Analysis of Rapid Securing Device for Helicopter Landing on NAVY Aircraft Carriers, Cooling of High Power Electronics, Noise and Vibration Measurement in Cast Iron Gears, Design of Automated Glass Ampule Sealing Device, Design of a Fog Chamber for Laser Testing and Testing of a Child Crash Test Dummy.

Another source for projects is research activities of the faculty. Many research projects involve design of an experimental test bed that fits well into the structure of the Junior/Senior Clinic. Research grants from federal and state govemment agencies such as the NSF, NASA, NJDOT and the NJ High-tech Workforce Grant supply the funding for the bulk of these types of projects. Recent projects include Development of a Drop Tower for Microgravity Experiments, Smart Materials Development,
Evaluation of School Bus Diesel Development of a Tunable Vibration Absorber Some

Junior/Senior Clinic projects are competitions run as competition (2003-present), ASME Design CAE Mini-Baja present), ASME Indoor Aerial Robotics Contest (2000. present) and NASA Reduced Gravity Contest (2005. Opportunities Program $(1999,2000$, and 2004$)$. Flight cond 2004). Student competitions provide excellent opportunities for putting coursework into practice, which is one of the main goals of the Junior/Senior Clinic. These experiences also give students the opportunity to observe other designs at the competition and reflect on the design process.

Finally, students are invited each semester to submit proposals to develop their own original inventions through to our innovative Venture Capital Fund., ${ }^{6,78}$ This is an exciting and unique opportunity for our students to find a need and develop a product. Funding of up to $\$ 2500$ per semester is available for each development team. Since its inception, over 20 entrepreneurial projects have been funded, leading to further funding from the National Collegiate Inventors and Innovators Alliance (NCIIA), development of several small businesses (SnoRhino ${ }^{\mathrm{TM}}$ and The Helping Hand) and products that are patented (Clutchknob: Guitar Tuning Peg) or patent-pending.

\section{IMPACT OF ENGINEERING CLINICS}

The clinic program results in numerous benefits for students and student learning as well as for faculty. In Freshmen Clinic I, students are introduced to Rowan University and the College of Engineering, taught survival skills and work on hands-on, multidisciplinary activities, which spark their interest in engineering and work with students from the other disciplines. In Spring, the competitive assessments teach students critical thinking skills and show students the multidisciplinary nature of most products and processes. Not only do the freshmen clinics begin to prepare the students with engineering skills, but the clinics also promote high levels of retention into the sophomore year.

Data from Institutional Research at Rowan University for Mechanical Engineering students entering between Fall 1999 and Fall 2004 are shown in Table 3. The number of students enrolling in Mechanical Engineering as freshmen from 1999 to 2001 does not include the students from those entering classes who transferred into Mechanical Engineering from General Engineering. At Rowan, General Engineering was not a degree program, but simply a category for students who were actually undeclared engineering majors. In Fall 2002, the General Engineering category was dropped since students were required to declare a major as incoming freshmen. Note that the percentage of students dropping out between freshmen and sophomore years is typically less than 20 percent. This is lower than estimates of loss rates of 30 percent in science and engineering ( $S \& E$ ), based on a longitudinal study by 
Center for Institutional Data Analysis and Exchange (CDEA 2000) at the University of Oklahoma." This study found that retention rates of $S \& E$ majors were higher at pore selective institutions and research institutions that also gward postgraduate (master's and doctoral) degrees. Thus, the retention rate would most likely be more pronounced against peer institutions.

\begin{tabular}{|c|c|c|c|}
\hline $\begin{array}{c}\text { Fall } \\
\text { Enroliment } \\
\text { Year }\end{array}$ & $\begin{array}{c}\text { Number of } \\
\text { students } \\
\text { declaring } \\
\text { Mechanical } \\
\text { Engineering }\end{array}$ & $\begin{array}{c}\text { Number of } \\
\text { students } \\
\text { retuming } \\
\text { after } \\
\text { freshman } \\
\text { year }\end{array}$ & Retention \\
\hline 1999 & 15 & 10 & $67 \%$ \\
\hline 2000 & 25 & 21 & $84 \%$ \\
\hline 2001 & 12 & 10 & $83 \%$ \\
\hline 2002 & 46 & 37 & $80 \%$ \\
\hline 2003 & 29 & 23 & $79 \%$ \\
\hline 2004 & 28 & 22 & $84 \%$ \\
\hline
\end{tabular}

TABLE 3: First year retention of Mechanical Engineering students enrolling between 1999 and 2004

Hands-on activities and teamwork in the Freshmen and Sophomore Clinics prepare students for the open-ended real-world projects of Junior/Senior Clinic. The writing and speaking experiences in Sophomore Clinic help students prepare for the reports, papers, resumes and presentations that are also important aspects of Junior/Senior Clinic.

Junior/Senior clinics provide students with valuable technical and professional experiences that give students advantages when applying for internships, scholarships, graduate school, and jobs after graduation. Rowan undergraduates can often point to conference presentations, journal publications, engineering reports, design and fabrication experience or field work as evidence of their exceptional preparation. Students working on industry sponsored projects have often received internship or fulltime job offers with the sponsoring company based on their experience and contacts. Students who participate in entrepreneurial projects have the opportunity to experience the patent-granting process firsthand. Anecdotal evidence and internship surveys from summer employers of students (polled on the students' technical, communications and teamwork skills) have been exemplary.

The clinic program was designed from its inception with the ABET EC2000 in mind and a strong focus on design, thus we are unable to compare these findings with a previous structure. By evaluating program features such as engineering clinic and teamwork, Hartman found that students' satisfaction was high for all students, whether they stayed in or left the program and whether they were male or female ${ }^{10}$, thus enforcing the student benefits of Clinic.

The Engineering Clinics have a positive impact on faculty development as well. During the startup phase of the engineering program at Rowan, 32 faculty members were hired over a 5 year period, the majority of which were early-career, tenure-track junior faculty members who responded to the challenges associated with starting an innovative new undergraduate engineering program. One of the key challenges for young faculty members at nonPh.D. granting institutions, is the need to maintain a level of scholarly activity necessary to stay current in their field of study and to remain competitive for career growth opportunities. We have found that the Junior/Senior Engineering Clinic, in concert with a modest full-time Master's program, has been highly effective as a means for engineering faculty members to maintain a high level of scholarly activity.

The design, build and test, approach is not only effective for student learning, it has also been shown to be effective for providing experimental hardware for scholarly pursuits. Since all engineering faculty members supervise two Junior/Senior clinic teams per semester as part of their normal course load, a research program can potentially have access to up to 8 undergraduate students per semester from four engineering disciplines. Since each student is expected to work at least 10 hours per week on their clinic project, the total amount of effort from these teams is approximately 2,500 person-hours per year for each year of a research project.

In addition to the benefits on design education, the engineering clinic has been highly effective in allowing undergraduate students to perform quality research as evidenced by the number of joumal and conference papers written by Rowan engineering faculty members with undergraduate co-authors. Indeed, the overwhelming majority of all of research done in the engineering program has been conducted through the use of multidisciplinary teams of undergraduate students working along side masters students in the clinic setting. This vertical integration has allowed the masters students to take an advisory role and allowed the undergraduates to be mentored in graduate research. In many cases, our own undergraduates stay for a masters degree and get their start through working on a project in clinic. The impact of undergraduate research at Rowan on the greater educational community can be measured by the high percentage of graduates from the program who go on to graduate study. Typically between 20 and 40 percent of a graduating engineering class will go on to graduate study at some of the nation's top graduate schools, which in recent years has included UC-Berkeley, Penn State, Princeton, Stanford, University of Michigan, University of Texas, and Virginia Tech.

Table 4 shows the number and percentage of Rowan graduating seniors continuing on to graduate school. According to 2006 statistics from the NSF, approximately 12 percent of those who graduate with a bachelor's degree in science and engineering (S\&E) continue in S\&E graduate studies. " Thus, Rowan graduates are more likely than their peers nationally to pursue graduate studies. We believe this can be attributed to their hands-on education and technical and professional skills acquired through undergraduate 
research opportunities and working closing with faculty and masters students.

\begin{tabular}{|c|c|c|c|}
\hline $\begin{array}{c}\text { Graduation } \\
\text { Year }\end{array}$ & $\begin{array}{c}\text { Number of } \\
\text { students } \\
\text { pursuing } \\
\text { graduate } \\
\text { studies }\end{array}$ & $\begin{array}{c}\text { Total } \\
\text { number of } \\
\text { students } \\
\text { graduating }\end{array}$ & $\begin{array}{c}\text { Percentage } \\
\text { of students } \\
\text { pursuing } \\
\text { graduate } \\
\text { studies }\end{array}$ \\
\hline 2000 & 6 & 28 & $21 \%$ \\
\hline 2001 & 5 & 17 & $29 \%$ \\
\hline 2002 & 9 & 22 & $41 \%$ \\
\hline 2003 & 11 & 24 & $46 \%$ \\
\hline 2004 & 13 & 42 & $31 \%$ \\
\hline 2005 & 5 & 27 & $19 \%$ \\
\hline 2006 & 12 & 25 & $48 \%$ \\
\hline
\end{tabular}

TABLE 4: Graduates pursuing graduate studies since Fall 2000

\section{SUMMARY}

The Engineering Clinic represents a paradigm for seamless incorporation of design throughout the four-year curriculum; and we believe it is readily adaptable by any College of Engineering. In addition to focusing on studentcentered, hands- and minds-on learning, the Clinics are multidisciplinary; allow for continuous practice and development of communications, teamwork and design skills; involves our constituencies; and easily incorporates the professional skill topics such as societal considerations, ethics and entrepreneurial skills. The Engineering Clinic sequence has been beneficial to both students and faculty as discussed and has contributed to high rates of retention and large percentages of students pursuing graduate studies in engineering. Further supporting data and comparison to other engineering design programs will be considered in the future. To foster adoption of the Engineering Clinic concept at other campuses, we have actively disseminated our ideas, materials, processes and results at conferences, through workshops and in publications.

\section{REFERENCES}

${ }^{1}$ Chandrupatla, T.R, Chen, J.C., Constans, E., Gabler, H.C., Kadlowec, J., Marchese, A., von Lockette, P., and Zhang, H. (2001) "Engineering Clinics: Integrating Design throughout the ME Curriculum," International Mechanical Engineering Conference and Exposition, New York, NY.

${ }^{2}$ Everett, J., Newell, J., Dahm, K., Kadlowec, J. Sukumaran, B., (2004) "Engineering Clinics: Bringing Practice Back into the Engineering Curriculum," Proceedings of the International Engineering Education Conference, Wolfhampton, England

${ }^{3}$ Newell, J., Ludlow, D. and Sternberg, S. (1997)

"Progressive development of oral and written communication skills across and integrated laboratory sequence," Chemical Engineering Education, vol. 31, pp. 116-11.
${ }^{4}$ Ludlow, D and Schulz, K. (1994) "Writing across the chemical engineering curriculum at the University of North Dakota," Journal of Engineering Education, vol. 83, pp.
161.

${ }^{5}$ Marchese, A., Constans, E., Dahm, K., Hollar, K., Hutto, D., Johnson, F., Sun., C, von Lockette, P. Kadlowec, J., Cleary, D. and Sukumaran, B. (2001) "The Sophomore Engineering Clinic I: Integrating Statics, Solid Mechanics and Product Development in a Sophomore Level Design Course." Proceedings of the American Society for Engineering Education Conference, St. Louis, MO

6 Marchese, A.J., Schmalzel, J.L., Mandayam, S.A., and Chen, J.C. (2001) "A Venture Capital Fund for Undergraduate Engineering Students at Rowan University." Journal of Engineering Education.

${ }^{7}$ Marchese, A. J., Mandayam, S., Chen, J. C., and Schmalzel, J. L (2000). "Reinventing the Design Curriculum." 4th Annual Conference of National Collegiate Invention and Innovation Alliance, Washington, DC

${ }^{8}$ Marchese, A. J., Schmalzel, J. L., Chen, J. C., Chandrupatla, T.R., Dahm, K., Mandayam, S. A., Ramachandran, R. P. and von Lockette, P. (2001). "The NCIIA Venture Capital Fund at Rowan University." Proceedings of the American Society for Engineering Education Conference, St. Louis, MO

${ }^{9}$ Science and Engineering Indicators 2002, Chapter 2: Higher Education Science and Engineering. http://www.nsf.gov/statistics/seind $02 / \mathrm{c} 2 / \mathrm{c} 2 \mathrm{~s} 2 \mathrm{htm}$ and also The Center for Institutional Data Analysis and Exchange (C-IDEA). 2000. 1999-2000 SMET Retention Report. Norman, OK: University of Oklahoma.

${ }^{10}$ Hartman, H. and Hartman, M. (2006) “Leaving Engineering: Lessons from Rowan University's College of Engineering." Journal of Engineering Education, January p. 49-61.

${ }^{11}$ Science and Engineering Indicators 2006, Chapter 2: Higher Education Science and Engineering. http://www.nsf.gov/statistics $/$ seind06/c2/c2s $2 \mathrm{htm}$ 